\title{
Apólogo das Amebas ${ }^{1}$
}

\author{
Claude Lévi-Strauss
}

\section{Tradução: Juliana P. Lima Caruso}

Laboratoire d'Anthropologie Sociale) - EHESS, Paris, Île-de-France, França E-mail: ju.limacaruso@gmail.com

\section{Tiago Hyra Rodrigues}

Centro Brasileiro de Análise e Planejamento - CEBRAP, São Paulo, São Paulo, Brasil E-mail: tiagohyra@gmail.com

\section{Beatriz Perrone Moisés}

Universidade de São Paulo - USP, São Paulo, São Paulo, Brasil

E-mail: perrone@usp.br 


\section{Resumo}

A versão original do texto a seguir faz parte de uma coletânea de textos dedicados a Françoise Héritier. Nesse breve apólogo, Lévi-Strauss retoma, em diálogo com grandes pensadores das humanidades e o saber da biologia, a grande questão da natureza do social - do lugar da sociabilidade. Trata-se aí de troca, de origens da linguagem, de relações entre humanos e grandes símios, de células e de transmissores químicos. A consideração atenta da vida das amebas enseja reflexões sobre cooperação e conflito, em conversa com a sociologia durkheimiana e a tradição filosófica; uma pérola de maturidade, que desafia barreiras disciplinares e pressupostos instalados, movendo a repensar grandes questões fundadoras.

Palavras-chave: Lévi-Strauss. Relações sociais. Formas de vida. Guerra. Aliança.

\section{Abstract}

The original version of the following text is part of a collection of texts dedicated to Françoise Héritier. In this brief apologue, Lévi-Strauss resumes, in dialogue with Humanities great thinkers and Biology knowledge, the grand question of the nature of the social - of the place of sociability. It discusses exchange, the origins of language, relations among humans and great apes, cells and chemical carriers. The attentive consideration of amoebas' life entices reflections on cooperation and conflict, in conversation with Durkheimian sociology and philosophical tradition; a jewel of maturity, which defies disciplinary boundaries and established assumptions, inducing to the rethinking of major founding issues.

Keywords: Lévi-Strauss. Social relations. Life forms War. Alliance. 
E

m seu seminário sobre a violência, cujo segundo volume foi lançado há alguns meses, Françoise Héritier toma como ponto de partida de sua reflexão "[...] a questão [...] frequentemente formulada, de saber se o homem é naturalmente, ou seja, biologicamente, violento e intolerante" ${ }^{\prime 2}$. Eu gostaria, como homenagem, de trazer uma contribuição a esse velho debate.

É impressionante que a morte, forma extrema da violência, tenha um lugar tão grande no pensamento de autores que pretendem explicar a origem da proibição do incesto e da exogamia e, ao mesmo tempo, a da sociedade. Freud, em Totem e tabu, procura tal origem no seio da família biológica, em contradição com Tylor que, em um célebre aforismo, afirmava que, muito cedo, os homens não tiveram outra escolha senão marrying out ou being killed out ${ }^{3}$.

Essas concepções, uma positiva e a outra negativa, estão em relação de simetria invertida. Os antropólogos podem encontrar-lhes respectivamente os méritos, segundo suas inclinações para as teorias ditas "da aliança" ou "da filiação", mas seria ingênuo crer que eles as tomam ao pé da letra. Já faz 50 anos que defendi a ideia de que, para conservar o valor de Totem e tabu, era necessário tratá-lo como um mito: não como reconstituição de eventos passados a respeito dos quais nada permite levantar hipóteses, mas como expressão de um sonho ao mesmo tempo duradouro e antigo que assombra o pensamento dos homens geração após geração.

O mesmo vale para o aforismo de Tylor. Ninguém alegará que enuncia uma verdade histórica. Ele traduz, sob a forma de mito, a visão retrospectiva que as famílias biológicas devem ter de um passado imaginário, para entenderem que a sociedade as proíba de levarem vidas separadas. 
Se nós insistíssemos em especular sobre o modo como as coisas realmente ocorreram - ambição quimérica visando a uma Antiguidade que, bem além do Homo sapiens, seria necessário contar em centenas de milhares ou mesmo em milhões de anos - não haveria nenhuma necessidade de postular a anterioridade lógica ou histórica das famílias biológicas. Bastaria reconhecer que nenhum meio social pode ser absolutamente fluido e indiferenciado, e que em razão de sua viscosidade específica apresenta uma textura granulosa. Agregados se fazem e se desfazem, mais visíveis uns aos outros do que as regiões mais instáveis, e entre os quais, enquanto duram, não por cálculo racional, mas por causa do pensamento simbólico, esboçam-se gestos de reciprocidade. Nesse sentido, pode-se dizer que a troca preexiste a seus atores.

Seria, portanto, equivocado julgar que a troca matrimonial possui natureza de contrato. Basta um único grau proibido para que a mecânica da troca se desencadeie no grupo como um todo, independentemente da consciência dos sujeitos. A troca é uma propriedade da estrutura social. Não que na sociedade tudo se troque (mesmo entre os índios da costa noroeste do Pacífico, exemplo sobre o qual Mauss fundou a teoria da troca, certos bens ou valores permanecem intransferíveis, como Boas já havia demostrado); mas, se não houvesse troca, não haveria sociedade ${ }^{4}$.

Colocar a sociabilidade antes da família apresenta, no entanto, uma dificuldade. Tomando o partido contrário, daríamos à sociedade um fundamento natural - ele deve ser procurado alhures. Cremos geralmente encontrá-lo aproximando as condutas humanas de comportamentos animais que ofereceriam sua prefiguração. É amplamente ilusório. Os antropólogos sabem há muito tempo que a relação entre o homem e o chimpanzé não é genealógica, mas de cousinage ${ }^{5}$, mas não tiram disso as devidas consequências: especializados em caminhos diferentes, o homem e os grandes símios se situam na mesma horizontal, no mesmo nível de geração. O estado atual de uns pouco nos ensina, portanto, sobre o passado próximo ou distante do outro.

O estudo da estrutura e das operações do código genético nos esclarece mais sobre a natureza da linguagem articulada, e reciprocamente, do que os esforços despendidos para inculcar algumas palavras ou fragmentos de frases em macacos bonobo (o que nos instrui 
sobre os macacos, não sobre a linguagem). Pois tudo se passa como se, à imagem das espirais de Vico, funções idênticas se manifestassem de forma recorrente em estágios distintos do conjunto dos seres vivos ${ }^{6}$. Não descobriremos a origem da linguagem articulada retomando as etapas de sua aquisição ou de seu aprendizado. Ela tem como modelo outra linguagem que a pré-forma, e cuja origem (bem como o mistério de sua reaparição de um nível ao outro com as mesmas propriedades) coloca problemas que ultrapassam a competência de psicólogos e linguistas.

Para compreender a natureza da sociabilidade, pode ser que, no mesmo espírito, seja necessário voltar-se para as formas mais elementares da comunicação: manifestando-se no nível celular, estão presentes em todos os seres vivos. No caso dos mamíferos que somos, a comunicação entre as células, que faz de cada corpo individual uma imensa sociedade, é assegurada por mensageiros químicos, eles mesmos tributários de uma substância, o monofosfato cíclico de adenosina (AMPc), esta intracelular, que desempenha um papel essencial.

Mas consideremos seres unicelulares como as amebas. Uma espécie terrícola vive sob dois regimes alternados. Habitualmente, cada ameba leva uma existência solitária em busca das bactérias das quais se nutre. Mas quando este alimento falta, algumas amebas, e depois pouco a pouco todas as outras, passam a secretar uma substância cujo efeito é fazê-las se atraírem. Elas convergem e se aglomeram em dezenas de milhares, tornam-se um corpo único de apenas um ou dois milímetros de altura, mas tornam-se uma verdadeira sociedade onde reina uma solidariedade que Durkheim teria chamado de orgânica. Os indivíduos se especializam, uns formando, juntos, um tubo oco para o qual as amebas mortas servirão de revestimento. Outras se posicionam no alto do tubo em um globo repleto de esporos. Essas se dispersarão e darão origem a uma nova geração sobre um solo mais rico em alimentos. Em sua fase social, de fato, as amebas têm a capacidade - que lhes falta no estado solitário - de se locomover em direção a fontes de umidade e de calor. Como Durkheim também teria dito neste caso, a sociedade é mais do que a soma dos indivíduos que a compõem...

Ora, essa substância atrativa que determina a passagem das amebas à vida social não é outra senão a AMP cíclica, segundo mensageiro, como vimos, da comunicação entre as células do corpo dos animais 
pluricelulares. Ela também está presente entre os vegetais, ao lado de outros mensageiros químicos comuns aos dois reinos; o que explica - como atestam desde tempos imemoriais os tratamentos à base de plantas - que as células do corpo humano compreendem, por assim dizer, as mensagens emitidas pelas dos vegetais: a linguagem que elas falam é, em parte, a mesma. Isso dá a esperança de que possamos um dia chegar a uma teoria unificada da comunicação intercelular.

Dos estudos de biologia que aqui resumo cabe realçar um ponto capital. A substância idêntica à AMP cíclica, que as amebas produzem em período de fome e que as induz a se agregarem, é a mesma que secretam as bactérias das quais as amebas se nutrem e que as guiam na direção de suas presas. Para passar de uma situação à outra, basta que a produção de AMP cíclica pelas amebas aumente a um grau tal que, tornadas insensíveis aos estímulos do ambiente, elas parem de caçar e respondam apenas a estímulos idênticos, mas endógenos, que as constituem em comunidade ${ }^{7}$.

Se fosse permitido, por meio de uma inversão dos gradientes, extrapolar aos animais pluricelulares aquilo que a observação dos seres unicelulares nos revela, a vida social apareceria entre os primeiros como resultado de uma atração entre os indivíduos, suficiente para que buscassem uns aos outros, mas não a ponto de, por excesso de atração, virem a se entredevorar ${ }^{8}$.

Os antigos já percebiam esta proximidade entre estados mutuamente exclusivos. Se, dizia um discípulo de Epicuro no $\mathrm{III}^{\circ}$ século antes de nossa era, "[...] removêssemos isto (as leis e prescrições, as realezas e os governos das cidades) viveríamos uma vida de bestas selvagens, e [...] um comeria o outro, o primeiro que encontrasse" ${ }^{\prime \prime}$.

Montaigne tem a respeito disso uma interpretação diferente da de Plutarco. Se, diz ele, deixássemos os homens livres para pensarem à vontade, "[...] segundo a imbecilidade (= fraqueza) e variedade infinita de nossas razões e opiniões, nos forjaríamos ao final deveres que nos levariam a nos comer uns aos outros" ${ }^{10}$. Poderíamos nos divertir vendo aí uma premonição de correntes de pensamento que, com o dadaísmo e o movimento modernista no Brasil, deram um valor emblemático ao canibalismo (Picabia) ou à antropofagia (Oswald de 
Andrade), interpretados como um apetite desregrado de comunicação que chega à devoração.

O pequeno exercício a que acabo de me dedicar não pretende provar nada: não passa de um apólogo. Justificado ou não, ele mostra que, longe de negar ou de ignorar a violência como frequentemente me acusaram, coloco-a na origem da vida social e a assento sobre fundações mais profundas que aqueles que, com o sacrifício ou a morte do bode expiatório, fazem nascer a sociedade de costumes que a supõem.

Mas se o apólogo contiver uma parte de verdade, deveríamos, custasse o que custasse, reconhecer que basta apenas um pequeno passo para ir da comunicação, como base da sociabilidade, à sociabilidade ela mesma como limite inferior da predação. Entre elas, haveria apenas uma diferença de grau. Formas elementares da vida celular, que toda a história humana e inumeráveis cenas da vida coletiva não desmentem, nos incitam a crer que sociabilidade e violência estão intrinsecamente ligadas.

\section{Notas}

1 Versão original: “Apologue des amibes". In: En Substances - Textes Pour Françoise Heritier. Sous la direction de Jean-Luc Jamard, Emmanuel Terray et Margharita Xanthakou. (C) Librairie Arthème Fayard, 2000, p.493-496.

2 F. Héritier, Séminaire de Françoise Héritier. De la Violence II. Paris, Odile Jacob, 1999, p. 322.

3 (N.T.) "Casar fora" e "ser morto fora", em inglês no original.

4 C. Lévi-Strauss, Les Structures élémentaires de la parenté, Paris, PUF, 1949; réédition 1967, Paris/La Haye, Mouton, p.51, 593, 609-611, 616.

5 (N.T.): Literalmente, "parentesco entre primos». Em francês, cousinage carrega também o sentido de um parentesco mais amplo e indeterminado.

6 R. Jakobson and L. Waugh, The Sound Shape of Language, Bloomington/Londres, Indiana University Press, 1979, p. 64-69.

7 J.T. Bonner, «Hormones in Social Amoebae and Mammals ", Scientific American, vol. CCXX, n.6, 1969, p.78-91 ; J.Roth et D. LeRoith, «Chemical Cross Talk. Why Human Cells Understand the Molecular Messages of Plants», The Sciences (Published by the New York Academy of Sciences), mai/juin 1987, p.53-54; E.Ben-Jacob et M. Levine, «The Artistry of Microorganisms», Scientific American, vol. CCLXXIX, n. 4, 1998, p. 61 ; La recherche, Paris, Société d'éditions sientifiques, n. 306, février 1998, p. 19.

8 C. Lévi-Strauss, L'Homme Nu, Paris, Plon, 1971, p. 617 ; Paroles données, Paris, Plon, 1984, p. 143-144.

9 Plutarque, "Contre l'épicurien Colotès ", Les Euvres meslées, trad. Amyot, Paris, G. de la Nouë, vol.II, 1584, p. 764-765. 
${ }^{10}$ M. de Montaigne, Les Essais, édition de Pierre Villey, Paris, PUF, coll. «Quadrige», n. $94-96,1988$, p. 488.

\section{Referências}

BEN-JACOB, E.; LEVINE, M. The Artistry of Microorganisms. Scientific American, [S.l.], v. CCLXXIX, n. 4, p. 61, 1998.

BONNER, J. T. Hormones in Social Amoebae and Mammals. Scientific American, [S.l.], v. CCXX, n. 6, p. 78-91, 1969.

HÉRITIER, Françoise. Séminaire de Françoise Héritier: de la Violence II. Paris, Odile Jacob, 1992. p. 322.

JACOBSON, R.; WAUGH, L. The Sound Shape of Language.

Bloomington; Londres: Indiana University Press, 1979. p. 64-69.

LA RECHERCHE. Société d'éditions scientifiques, Paris, n. 306, p. 19, février 1998.

LÉVI-STRAUSS, Claude. Les Structures élémentaires de la parenté. Paris: PUF, 1949; réédition 1967. Paris/La Haye, Mouton, p. 51, 593, 609$611,616$.

LÉVI-STRAUSS, Claude. L'Homme Nu. Paris: Plon, 1971. p. 617.

LÉVI-STRAUSS, Claude. Paroles données. Paris: Plon, 1984. p. 143-144.

MONTAIGNE, Michel de. Les Essais, édition de Pierre Villey, Paris, PUF, coll. Quadrige, n. 94-96, p. 488, 1988.

PLUTARQUE. Contre l'épicurien Colotès. Les OEuvres meslées. Trad.

Amyot, Paris, G. de la Nouë, v. II, p. 764-765, 1584.

ROTH, J.; LeROITH, D. Chemical Cross Talk. Why Human Cells Understand the Molecular Messages of Plants. The Sciences (Published by the New York Academy of Sciences), mai/juin, p. 53-54, 1987.

Recebido em 07/08/2018

Aceito em 20/10/2018

Este texto está publicado sob uma Licença Creative Commons - Atribuição-NãoComercialCompartilhaIgual 4.0 Internacional - CC BY NC AS.

Mais detalhes em: https://creativecommons.org/licenses/by-nc-sa/4.0/deed.pt_BR 